\title{
Dermoid cyst: an unusual location
}

\author{
Sarita R J Gonsalves, ${ }^{1}$ Geover Joslen Lobo, ${ }^{2}$ Norman Mendonca ${ }^{3}$
}

${ }^{1}$ Department of

Ophthalmology, Kasturba Medical College, Manipal, Karnataka, India ${ }^{2}$ Kasturba Medical College Manipal, Karnataka, India ${ }^{3}$ Father Muller Medical College, Mangalore, Karnataka, India

\section{Correspondence to} Dr Sarita R J Gonsalves, gonsalvessarita@gmail.com

\section{DESCRIPTION}

We report a case of a dermoid cyst of the lower lid, such a presentation has not been reported so far. A 40-year-old woman presented with a painless swelling of the lower eye lid of 20 years duration, that was gradually increasing in size. No diplopia, diminution of vision or other ocular symptoms. An examination revealed a firm, non-tender $1.5 \times 2.0 \mathrm{~cm}$ swelling in the right lower lid. The overlying skin, underlying tarsal plate and bone were free with no displacement of the globe (figure 1). Extraocular movements were normal. The visual acuity was $6 / 6, \mathrm{~N} 6$, fundus were normal. Blood counts were normal, CT orbit did not show erosion of the bone or orbit involvement. Fine-needle aspiration cytology was suggestive of dermoid cyst. The cyst was excised without spilling the contents. Thick cheesy material was noted with few hairs, suggestive of a dermoid cyst (figure 2). Diagnosis was confirmed on histopathology.The cyst did not recur and the site healed well with no scarring. A dermoid cyst is a choristoma occurring at the sites of closure of the suture lines during embryonic development. The most common site is the lateral angle of the orbit, medial angle, limbal, deep orbital in that order. ${ }^{1}$ Dermoid cysts in the upper lid with attachment to the tarsus have been reported. ${ }^{2}$ The lower lid is an uncommon site. Slow enlargement is due to the accumulation of debris within the lumen. Cysts located deep in the orbit may compress the optic nerve, and cause proptosis, restriction of eye movements. ${ }^{3}$ Treatment is en bloc excision.

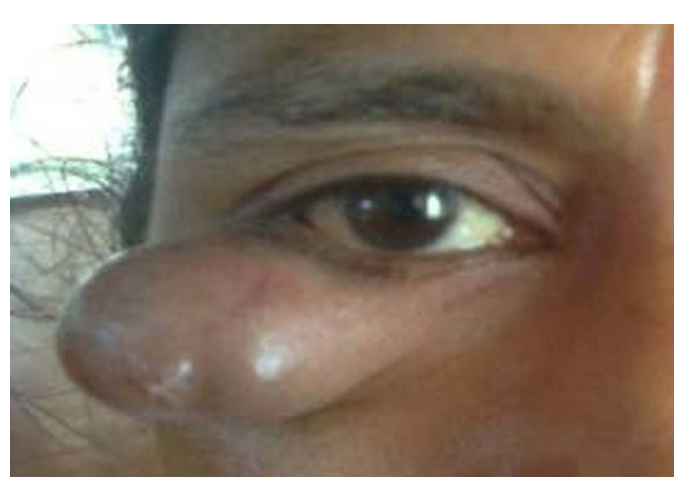

Figure 1 Dermoid cyst of the lower lid, without \begin{abstract}
attachment to the underlying tarsus.
\end{abstract}

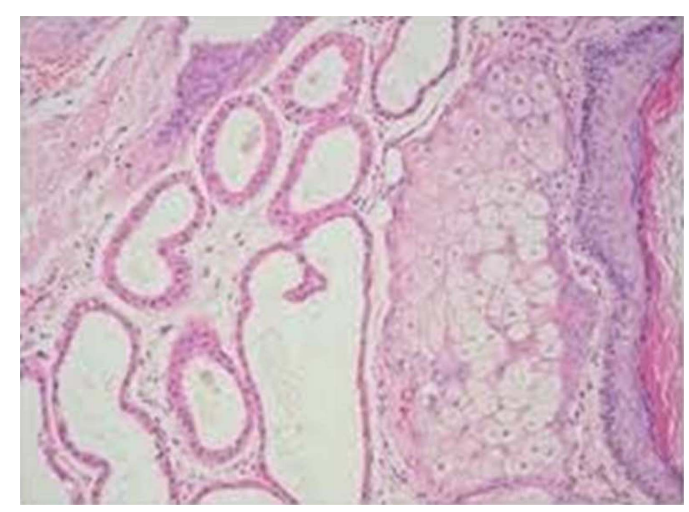

Figure 2 Histopathology section showing a typical dermoid cyst.

\section{Learning points}

- Orbital dermoid cysts located superficially in and around the orbit present as subcutaneous or subconjunctival discrete well-circumscribed swellings in childhood.

- Complete surgical excision with intact capsule is done to prevent dissemination of the contents.

- The present case is unusual, as the site of the dermoid cyst is the lower lid in an adult which is uncommon, with no pressure symptoms.

Contributors SRJG was involved in the acquisition, analysis and formulation of the data. GJL was involved in data collection. NM was involved in the approval of the data.

Competing interests None.

Patient consent Obtained.

Provenance and peer review Not commissioned; externally peer reviewed.

\section{REFERENCES}

1 Sherman RP, Rootman J, Lapoint JS. Dermoids-clinical presentation and management. Br J Ophthalmol 1984;68:642-52. 
Copyright 2013 BMJ Publishing Group. All rights reserved. For permission to reuse any of this content visit http://group.bmj.com/group/rights-licensing/permissions.

BMJ Case Report Fellows may re-use this article for personal use and teaching without any further permission.

Become a Fellow of BMJ Case Reports today and you can:

- Submit as many cases as you like

- Enjoy fast sympathetic peer review and rapid publication of accepted articles

- Access all the published articles

- Re-use any of the published material for personal use and teaching without further permission

For information on Institutional Fellowships contact consortiasales@bmjgroup.com

Visit casereports.bmj.com for more articles like this and to become a Fellow 